\title{
Air Microbial Contamination at the Holy Mosque, Makkah, Saudi Arabia
}

\author{
A.A.ABDEL HAMEED* and T. HABEEBALLAH \\ Department of Environmental and Health Research, The custodian of the Two Holy \\ Mosques, Institute for Hajj and Umrah, Umm-Al Qura University, Saudi Arabia - 21955 \\ http://dx.doi.org/10.12944/CWE.8.2.03
}

(Received: July 15, 2013; Accepted: August 20, 2013)

\begin{abstract}
Airborne microbial contamination was collected from the main directions of the holy mosque (Al-Haram mosque), Makkah city, by using the gravitational method.Bacteria, fungi and actinomycete concentrations ranged between $1470-21800 \mathrm{CFU} / \mathrm{m}^{3} ; 44-572 \mathrm{CFU} / \mathrm{m}^{3}$, and $0.0-264 \mathrm{CFU} / \mathrm{m}^{3}$, respectively at all directions. Bacterial concentrations significantly differed between directions, and Gram positive bacteria constituted $~ 90-100 \%$ of the total bacterial isolates. Gammaproteo bacteria were the common Gram negative bacteria, and Aspergillus was the predominant fungal genera. Mesophilic bacteria negatively related $(P<0.05)$ with relative humidity. Human activities had more effective influence on the microbial concentrations than the meteorological factors.
\end{abstract}

Key words: Air, Biocontamination, Directions, Biodiversity, The holy mosque, Makkah.

\section{INTRODUCTION}

Atmospheric particles of biological origin are diverse group of microorganisms and their execrations. Airborne microorganisms originate from many sources: animal, human, and vegetation. The number and composition of airborne microorganisms have increased in the urban and rural areas ${ }^{1}$.The presence of microorganisms depends on seasonality, geographical conditions, meteorological factors, type of sources ${ }^{2,34}$, and air pollution ${ }^{5}$.Airborne microorganisms may contribute $\sim 20 \%, 22 \%$ and $10 \%$ of the total particulate matters in the remote continental, populated-continental, and remote maritime environments, respectively ${ }^{6}$. The concentrations and composition of airborne microorganisms undergoes daily, weekly and seasonally changes ${ }^{7}$.

Millions of people arrive to the Holy City, Makkah city, particularly in the Ramadan month,the fasting month, every year. Microbial contamination represents a dangerous risk factor in many human activities areas $^{8}$, as airborne microorganisms cause allergy, infections, and toxicity ${ }^{9,10}$. Some studies have been carried out on microbial contamination in the atmosphere of Saudi Arabia cities: such as Riyadh ${ }^{11}$, Hofuf ${ }^{12}$, Makkah ${ }^{13}$, and Taief ${ }^{14}$. However few studies have been performed on the airborne microorganisms in the area near and around the holy mosque. The results showed that microbial concentrations differed depending on methodology and sampling location ${ }^{15,} 16$.

Until now no complementary studies have dealt with airborne microbial community at the main directions of the holy mosque that may be differed in their human activitiesand topographical features. The evaluation of microbial contamination, in places at risk, is considered a basic step toward prevention and control. The present study aims to gain more insight into the variability of airborne bacteria, fungi, and actinomycetes at the main directions of the holy mosque, in order to determine its microbial air quality and give site specific information.

\section{MATERIALS AND METHODS}

\section{Site description}

The Holy City,Makkah, is located at an 
altitude of $277 \mathrm{~m}, 21^{\circ} 29^{\prime} \mathrm{N} 39^{\circ} 45^{\prime} \mathrm{E}$, and $\sim 80 \mathrm{~km}$ inland from the Red Sea, with a population of $\sim 2,000,000^{17}$. The area around the holy mosque comprises the old city; which is characterized by heavy traffic, parking, hotels, and hospitals with no predominant plant cover. Four sampling sites were selected to carry out the present study. Air samples were collected at the main directions (North, South, West and East) of the holy mosque (Fig. 1), in order to represent various geographical features and human activities. A brief summary of the general human activities and environmental characteristics at each direction are shown in Table 1.

During every sampling event, temperature and relative humidity were measured using a portable Psychrometer (Extech -model 42270, China), adjusted to record data at every $10 \mathrm{~min}$ intervals. Temperatures ranged between $27-35^{\circ} \mathrm{C}$ with mean values of $30.3^{\circ} \mathrm{C}, 29.6^{\circ} \mathrm{C}, 31.4^{\circ} \mathrm{C}$ and $30.8{ }^{\circ} \mathrm{C}$ at the North, South, East, and West, respectively. Relative humidity ranged between 32$63 \%$ with mean values of $38.7 \%, 43 \%, 34 \%$ and $42 \%$ at the corresponding directions, respectively. Wind speed records were obtained from The Presidency of Meteorology and Environment, Makkah. The wind speed ranged between 0.5 to 1.5 $\mathrm{m} / \mathrm{s}$, with north-east was the prevailing wind direction.

\section{Sampling strategy}

A total of 16 samples were collected between $19^{\text {th }}$ to $27^{\text {th }}$ days of Ramadan (7-15, August, 2012). Two consecutive samples were collected every sampling event. Air samples were collected at $\sim 1$ - $3 \mathrm{~m}$ height above the ground level, between 19.00 PM and 24.00 AM, the night time. This time was chosen because it is the time of the overcrowding in the holy mosque during the Ramadan month. The gravitational method was used to collect airborne culturable microorganisms. The Petri plates, in triplicate, containing trypticase soya agar, czapek's dox agar, and starch casein agar (Hi-Media Laboratories, Mumbai, India) media were used to collect bacteria, fungi and actinomycetes, respectively. The sampling time varied within 10-20-min. The exposed plates were incubated for $5-7$ days at $28^{\circ} \mathrm{C}$ for fungi; $48 \mathrm{hrs}$ at 22 and $37{ }^{\circ} \mathrm{C}$ for psychophilic, and mesophilic bacteria; respectively, and 10 days at $25{ }^{\circ} \mathrm{C}$ for actinomycetes.
The resultant colonies were counted and converted into colony forming unit per cubic meter of air $\left(\mathrm{CFU} / \mathrm{m}^{3}\right)$ using Omeliansky formula ${ }^{18}$ :

$$
\mathrm{N}=5 \mathrm{a} \times 10^{4}(\mathrm{bt})^{-1}
$$

Where: $\mathrm{N}=$ colony forming unit per cubic meter of air $\left(\mathrm{CFU} / \mathrm{m}^{3}\right) \mathrm{a}=$ number of colonies per Petri dish, $b=$ dish square centimeter, $t=$ exposure time (min).

All the grown fungal colonies, and five to ten bacterial colonies which appear in more than $5 \%$ of trypticase soya agar were purified and identified to the genus level. Aspergillus was identified to the species level. The bacterial isolates were identified on the basis of Gram stain, oxidase, and catalase tests ${ }^{19}$. Fungal isolates were identified using macroscopic and microscopic features ${ }^{20-23}$.

\section{Statistical analysis}

Data was analyzed using the non parametric statics. The kruskal Wallis test was used to compare microbial contamination at the different directions $(p<0.05)$, followed by post hoc test (Student t-test). The assumption for this test is that the samples from different groups are randomly independent.Spearman's rank correlation test $\left(r_{s}\right)$ was used to determine the relationships between microbial concentrations and meteorological factors.

\section{RESULTS}

The range and mean concentrations of airborne culturable microorganisms at the main directions of the holy mosque are shown in Table 2. The bacterial concentrations ranged between 1470- $21800 \mathrm{CFU} / \mathrm{m}^{3}$, with mesophilic bacterial concentrations exceeded psychophilic concentrations. The highest bacterial concentration was found at the north direction, and the lowest at the East. Fungal concentrations ranged between $44-572 \mathrm{CFU} / \mathrm{m}^{3}$, with the highest concentrations were found at the North and West directions. Airborne actinomycete concentrations were found in the range of $0-264 \mathrm{CFU} / \mathrm{m}^{3}$ (Table 2). Mesophilic and psychophilic bacterial concentrations significantly differed between the all directions $(P<0.05)$, however fungi and actinomycete 
concentrations did not show any significant differences.

A total of 502 bacterial isolates belonging to 11 genera were identified (Fig. 2). Gram positive and negative bacteria constituted $90-100 \%$ and 2.4
- $9.4 \%$, respectively of the total isolates. Staphylococci (4.2-26\%), and Bacillus (5.5-30.9\%) were the dominant Gram positive bacteria. Streptococci and spore-formers were only detected at the north and south directions, respectively. Gammaproteobacteria (Pseudomonas) constituted

Table 1: A brief description of the environmental features around the holy mosque

\begin{tabular}{|c|c|c|c|c|}
\hline Direction & Denomination & \multicolumn{3}{|c|}{ General environmental characteristics } \\
\hline North & Shamiah & \multicolumn{3}{|c|}{$\begin{array}{l}\text { Constructions, demolition, unpaved roads, small workshops, dusty } \\
\text { environment, light vehicles (motorcycle) }\end{array}$} \\
\hline South & Ajeadh & \multicolumn{3}{|c|}{$\begin{array}{l}\text { Considered closed area, tall buildings, steady air, high Worshipers } \\
\text { density, spray humidifiers. }\end{array}$} \\
\hline East & Ghaza & \multicolumn{3}{|c|}{$\begin{array}{l}\text { Considered open area, good natural air ventilation, library, near tc } \\
\text { bus parking. }\end{array}$} \\
\hline West & Shobaikah & \multicolumn{3}{|c|}{$\begin{array}{l}\text { Similar to south direction, high Worshipers density, fair natura } \\
\text { ventilation, spray humidifiers. }\end{array}$} \\
\hline \multicolumn{5}{|c|}{$\begin{array}{l}\text { Table 2: The range and mean concentrations of airborne microorganisms } \\
\text { at the main directions of the holy mosque }\end{array}$} \\
\hline \multirow[t]{2}{*}{ Indicator } & \multicolumn{4}{|c|}{$\mathrm{CFU} / \mathrm{m}^{3}$} \\
\hline & North & South & East & West \\
\hline Bacteria & $\left(8.76 \times 10^{3}-1.74 \times 10^{4}\right)$ & $\left(2.38 \times 10^{3}-1.58 \times 10^{4}\right)$ & $\left(1.47 \times 10^{3}-3.21 \times 10^{3}\right)$ & $\left(1.54 \times 10^{3}-4.76 \times 10^{3}\right)$ \\
\hline $22^{\circ} \mathrm{C}$ & {$\left[1.13 \times 10^{4} \pm 4.09 \times 10^{3}\right]$} & {$\left[6.65 \times 10^{3} \pm 6.16 \times 10^{3}\right]$} & {$\left[2.29 \times 10^{3} \pm 7.38 \times 10^{2}\right]$} & {$\left[3.25 \times 10^{3} \pm 1.56 \times 10^{3}\right]$} \\
\hline Bacteria & $\left(1.10 \times 10^{4}-2.18 \times 10^{4}\right)$ & $\left(2.25 \times 10^{3}-1.76 \times 10^{4}\right)$ & $\left(1.85 \times 10^{3}-3.66 \times 10^{3}\right)$ & $\left(1.94 \times 10^{3}-6.22 \times 10^{3}\right)$ \\
\hline $37^{\circ} \mathrm{C}$ & {$\left[1.41 \times 10^{4} \pm 5.13 \times 10^{3}\right]$} & {$\left[8.60 \times 10^{3} \pm 6.63 \times 10^{3}\right]$} & {$\left[2.86 \times 10^{3} \pm 7.66 \times 10^{2}\right]$} & $\left.4.11 \times 10^{3} \pm 2.02 \times 10^{3}\right]$ \\
\hline \multirow[t]{2}{*}{ Fungi } & $\left(1.17 \times 10^{2}-4.40 \times 10^{2}\right)$ & $\left(1.17 \times 10^{2}-5.72 \times 10^{2}\right)$ & $\left(4.4 \times 10^{1}-2.34 \times 10^{2}\right)$ & $\left(4.4 \times 10^{1}-3.08 \times 10^{2}\right)$ \\
\hline & {$\left[2.60 \times 10^{2} \pm 1.61 \times 10^{2}\right]$} & {$\left[2.60 \times 10^{2} \pm 2.12 \times 10^{2}\right]$} & {$\left[1.461 \times 10^{2} \pm 8.0 \times 10^{1}\right]$} & {$\left[1.98 \times 10^{2} \pm 1.54 \times 10^{2}\right]$} \\
\hline \multirow{2}{*}{$\begin{array}{l}\text { Actinom- } \\
\text { ycetes }\end{array}$} & $\left(8.8 \times 10^{1}-2.64 \times 10^{2}\right)$ & $\left(8.8 \times 10^{1}-1.76 \times 10^{2}\right)$ & $\left(5.9 \times 10^{1}-1.76 \times 10^{2}\right)$ & $\left(0.00-1.32 \times 10^{2}\right)$ \\
\hline & {$\left[1.54 \times 10^{2} \pm 8.4 \times 10^{1}\right]$} & {$\left[1.28 \times 10^{2} \pm 3.6 \times 10^{1}\right]$} & {$\left[1.03 \times 10^{2} \pm 5.1 \times 10^{1}\right]$} & {$\left[7.7 \times 10^{1} \pm 5.5 \times 10^{1}\right]$} \\
\hline
\end{tabular}

(Range), [mean \pm standard deviation]

Table 3: Similarity triangle depicting agreement ratios among microbial isolates at the different directionsof the holy mosque

\begin{tabular}{|c|c|c|c|c|c|c|c|c|}
\hline \multirow[t]{2}{*}{ Direction } & \multicolumn{4}{|c|}{ Bacteria } & \multicolumn{3}{|c|}{ Fungi } & \multirow[b]{2}{*}{ W } \\
\hline & $\mathbf{N}$ & $S$ & $E$ & W & $\mathbf{N}$ & $S$ & $E$ & \\
\hline $\mathrm{N}$ & 1.0 & 0.84 & 0.94 & 0.88 & 1.0 & 0.28 & 0.65 & 0.46 \\
\hline$S$ & & 1.0 & 0.7 & 0.94 & & 1.0 & 0.38 & 0.11 \\
\hline$E$ & & & 1.0 & 0.82 & & & 1.0 & 0.46 \\
\hline W & & & & 1.0 & & & & 1.0 \\
\hline
\end{tabular}

N: North, S: South, E: East, W: West 
$8.75 \%$ of the total isolates at the south direction (Fig. 2). A total of 112 fungal isolates belonging to 19 genera were identified (Fig. 3). Aspergillus represented by Aspergillus fumigatus, Aspergillus niger and Aspergillus flavus. Aspergillus niger (14.27\%- 46.9\%) and Fusarium (6.90\% - 13.62\%) were the common fungal isolates. The highest fungal diversity was found at the south direction, among which Epicoccum, Mucor, Trichophyton, Chaetomium, Cladosporium, Alternaria, Emericella were detected.

Table 3 shows the agreement ratios between the identified microbial isolates between directions. The agreement ratio is used to compare the identified microorganisms among sampling

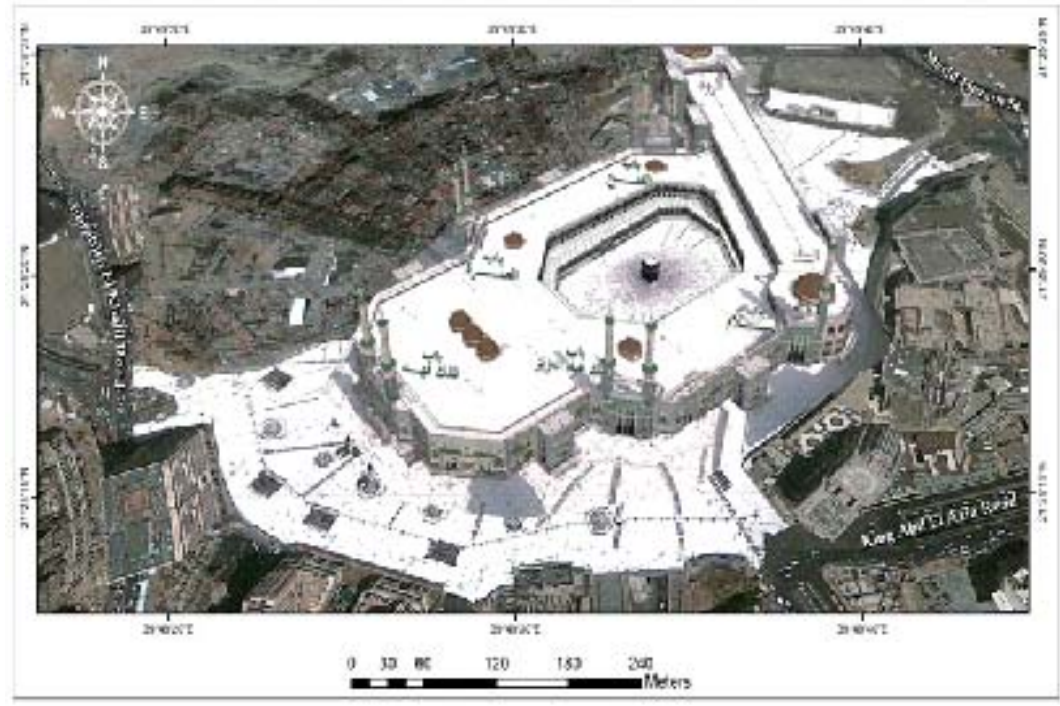

Fig. 1: A diagram of the holy mosque showing sampling points
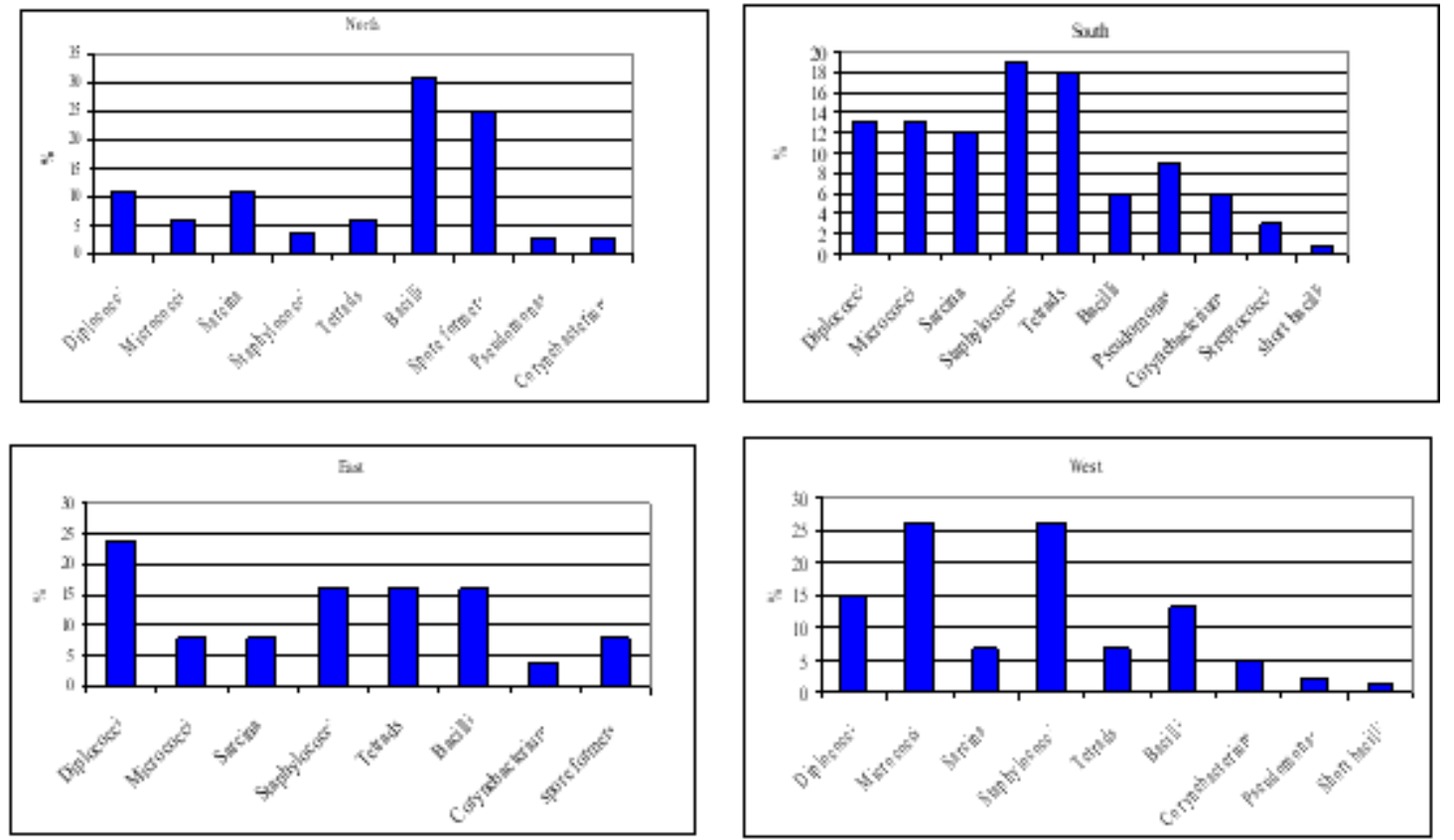

Fig. 2: Identification of airborne bacterial genera at the different directionsof the holy mosque 

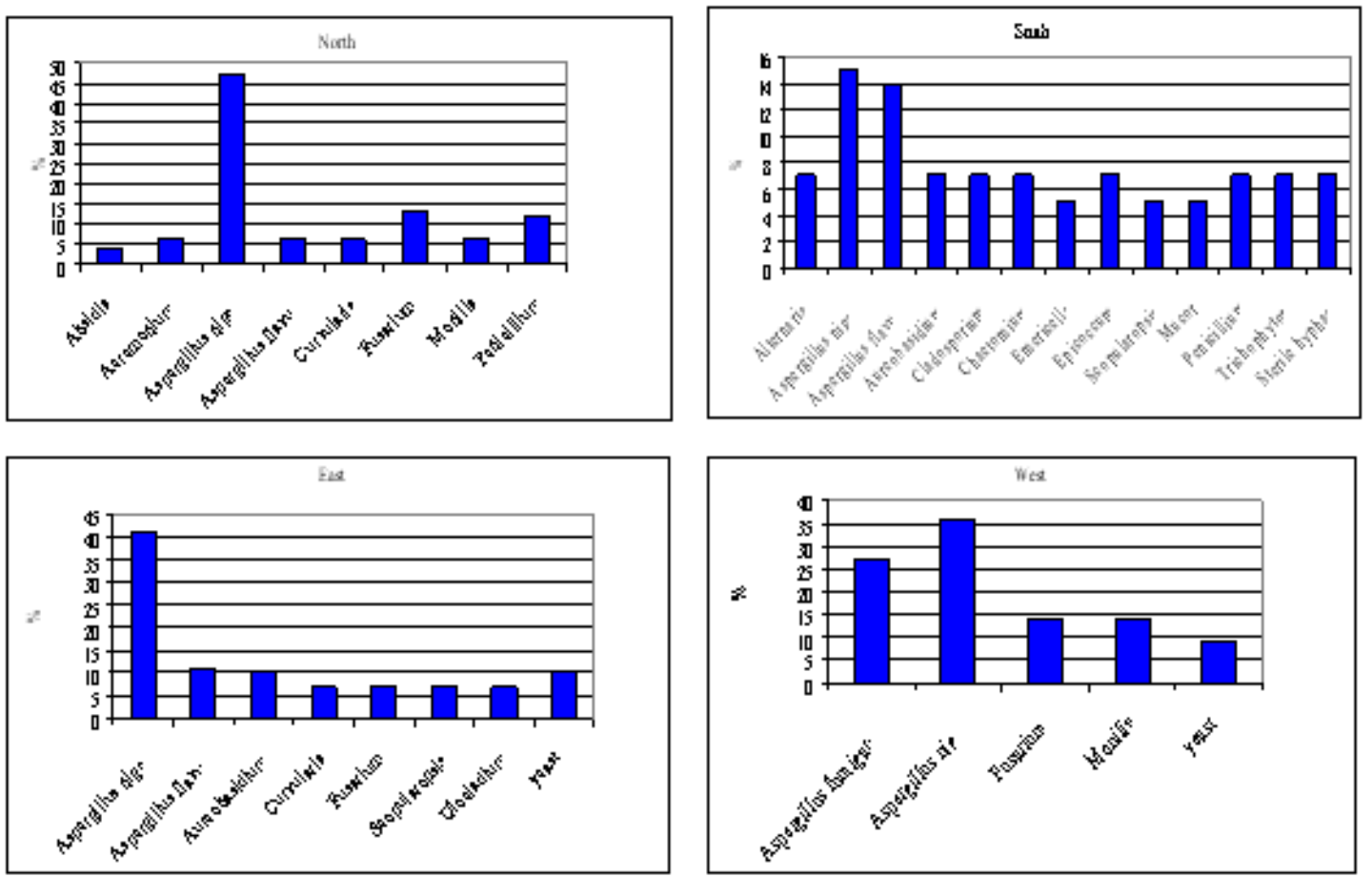

Fig. 3: Identification of airborne fungal genera at the different directionsof the holy mosque

sites, as it reflects the number of shared genera at the different sites in relation to the total number of genera ${ }^{24}$. High agreement ratios were found between bacterial genera at the all directions. The agreement ratios for fungi were relatively lower than bacteria, the highest ratio $(0.65)$ was found between the North and East directions.

No clear relationships were found between the meteorological parameters and airborne microorganisms. The relationships differ according to type of bio-contaminant and direction. However, relative humidity was considered the main factor affecting survivability of mesophilic bacteria $(r=-0.4-0.8)$. Actinomycetes negatively related with temperature, however fungi negatively and positively related with relative humidity, and temperature, respectively. Wind speed show weak negative and positive relationships with microbial concentrations.

\section{DISCUSSION}

Airborne microbial contamination is a significant issue in the crowded centers and cities, as air serves as a transmission vehicle for pathogens that have linked with adverse health effects ranging from infectious diseases to allergies and cancer ${ }^{25}$. Airborne microorganisms affect individuals who are at risk, immune-compromised, elders and children, particularly in overcrowded areas, however, human responses depend on type of microorganism, and individual's immune system ${ }^{26}$. Various sampling methods are used to collect airborne microorganisms including, impaction, impingement, filtration and gravity deposition ${ }^{27}$. Passive and active sampling methods are based on different principles. The passive samplers yielded data with the lowest standard deviation in comparison with the active samplers ${ }^{28}$. In the present study, the gravitational method was used because it is a simple, cheap, and many places can be checked at the same time.The gravitational method is a non-quantitative method ${ }^{29}$, as it is affected by the size and shape of the particles, and motion of the surrounding atmosphere ${ }^{30}$. Omeliansky formula is not a universal conversion formula; however it is used to allow comparing our results with other results that were obtained by using the active samplers. 
Airborne microbial concentrations ranging from 4,500-10,000 CFU/m³ have been suggested as the upper limit for ubiquitous bacterial aerosols ${ }^{31}$, and concentration $<100 \mathrm{cfu} / \mathrm{m}^{3}$ may be unhealthy to immunosuppressed people ${ }^{32}$. In the present study bacterial concentrations exceeded $10^{4} \mathrm{CFU} / \mathrm{m}^{3}$ at the North and South directions. However, fungal concentrations did not exceed the allowable guideline limit value of $500 \mathrm{CFU} / \mathrm{m}^{333}$. Actinomycetes exceeded $100 \mathrm{CFU} / \mathrm{m}^{3}$, strongly contaminated air, and $10-100 \mathrm{CFU} / \mathrm{m}^{3}$, moderately contaminated air at some directions as suggested by Polish Standards ${ }^{34}$.

Airborne bacterial concentrations exceed $1 \times 10^{4} \mathrm{CFU} / \mathrm{m}^{3}$ over land ${ }^{35}$, as bacteria may be suspended as individual cells or attached to other particles such as soil and leaf ${ }^{36}$. Airborne fungal concentrations generally ranged from $10^{0}-10^{3} \mathrm{CFU} /$ $\mathrm{m}^{337}$, and averaged $\sim 10^{4} \mathrm{CFU} / \mathrm{m}^{3}$ in the urban air ${ }^{1}$. Airborne actinomycetes averaged $10^{2} \mathrm{CFU} / \mathrm{m}^{3}$ in the Cairo city centre ${ }^{38}$, as actinomycetes are highly dependent on the amount of dust in the air ${ }^{39}$.

Airborne microbial contamination is affected by multiple variables. These variables continuously changed, such as anthropogenic influence, human activity, topography, microenvironmental conditions, type of sources, and seasonality ${ }^{1}$. In the present study traffic flow disturbed dust particles at the north direction that might be the reason for increasing of microbial concentration. The lowest microbial concentration was found at the East direction. This is attributed to the absence of direct human disturbances, and good natural ventilation. Generally microbial concentrations in the urban environment are influenced by human activities ${ }^{40}$, and their composition varies in different cities ${ }^{41}$. In the present study there were unclear correlations found between airborne microorganisms and meteorological factors. This is attributed to the influence of irregular disturbances and human activities, which may have more influence on microbial concentrations than meteorological factors near the holy mosque. The lack of significant relationships does not mean that meteorological factors have no effects on microbial survivability, because in un-standardized conditions severe microbial variations are expected.
In the present study Gram positive bacteria were common. This could be explained on the bases of their cell wall structure and continuous sources. The low frequent detection of Gram negative bacteriais attributed to their sensitivity to the air environment ${ }^{41}$, and the initial shock due to desiccation after aerosolization ${ }^{42}$.Firmicutes, Proteobacteria and Actinobacteria are common bacterial types in the urban environment, where Gammaproteobacteria and Betaproteobacteria have been regularly identified ${ }^{1}$. Mouli et al. ${ }^{43}$ found airborne Gram positive bacteria in the range of $60 \%$ - $90 \%$ of the total bacterial population, in Tirupati, India; however Bacillus constituted $47.62 \%$ and Acinetobacteria $14.27 \%$ in the atmosphere of $\mathrm{El}$ Taief, Saudi Arabia ${ }^{44}$. Bacillus, Micrococcus and Staphylococci differed from place to place depending on the micro-environment ${ }^{45}$. In the present study the frequent detection of Pseudomonas species at the south direction is of a particular interest as the spray humidifiers, and water reservoirs are suspected to be their sources.

Airborne fungi is likely to be similar in most parts of the world, however the dominating genera may differ from area to another, depending on the density of plant cover, geographical location, and human activity ${ }^{46}$. In the present study, Alternaria, Penicillium and Cladosporium were found in low counts because Penicillium and Cladosporium favor low temperature conditions, and sensitive to solar radiation ${ }^{47}$. Alternaria proliferates in the presence of suitable humidity, temperature, and vegetation debris ${ }^{48}$, these conditions are not available in the Saudi Arabia, as low humidity, high temperature and no permanent plant cover are the main characters of Makkah city. Fusarium can grow in water pipes, fresh water and humidifiers ${ }^{49}$, this confirms the presence of Fusarium in the air around the holy mosque. In the present study phyloplane and water indicators fungi ${ }^{50}$ were detected in lower counts than soil fungi.

Actinomycetes may induce respiratory symptoms ${ }^{10}$, streptomycetes have been implicated in many diseases and several species stimulate lung macrophage reactions that lead to inflammation of the lung ${ }^{9}$. Aspergillus, Eurotium, Penicillium and Trichoderma species have been known as a cause of allergenic alveolitis ${ }^{51}$. 
Aspergillus flavus and Aspergillus fumigatus cause aspergillosis $^{52}$. Gram negative bacteria are an important source of endotoxins, which are the main pulmonary immunotoxicants ${ }^{53}$. Gram-positive bacteria should also be regarded as potential immunotoxicants ${ }^{54}$.Bacillus species have been found to be associated with allergic alveolitis ${ }^{55}$.The potential for extensive transmission of airborne infectious agents is present in large public settings; however the duration of exposure may be short. At the holy mosque, particularly in the Ramadan month, the duration of exposure to microbial contamination may be extended to be >10 hour/ day and the probability of infection may be present. Therefore a program for surveillance, prevention and control of airborne microbial contamination should be established at the holy mosque.

\section{CONCLUSION}

Airborne microbial concentrations not significantly varied between the main directions of the holy mosque. Airborne bacteria were the main microbial contaminants. The biodiversity of bacterial and fungal generawere higher at the south direction; however the north had the largest microbial concentrations. The anthropogenic activities are the main variables controlling air bio-contamination around the holy mosque. The spray humidifiers are suspected to be the main emission source of Pseudomonasbacteria. People may be exposed to infectious agents at the holy mosque; therefore the microbial contents should be included in the air quality standards and reports.

\section{REFERENCES}

1. Després V.R., Huffman J. A., Burrows S .M, Hoose C, Safatov A. S., Buryak G., FröhlichNowoisky J., Elbert W., Andreae M. O., Pöschl U., Jaenicke R., Tellus B, 64:15598 (2012).

2. De Linares C., Belmonte J., Canela M., Díaz de la Guardia C., Alba-Sanchez F., Sabariego S., Alonso-Pérez S.,Agricultural and Forest Meteorology, 150: 1491 (2010).

3. Womack A.M., Bohannan B.J.M., Green J.L., Phil. Trans. R. Soc. B, 365(1558): 3645 (2010).

4. Brodie E.L., DeSantis T.Z., Parker J.P.M., Zubietta I.X., Piceno Y.M., Andersen G.L.,PNAS, 104: 299 (2007).

5. Abdel Hameed A.A., Khoder M.I., Ibrahim Y.H., Saeed Y., Osman M.E., Ghanem S., Sci. Total Environ., 414: 696 (2012).

6. Matthais-Maser S., Obolkin V., Khodzer T., Jaenicke R.,Atmospheric Environment, 34: 3805 (2000).

7. Kaarkainen P., Meklin T., Rintala H., Hyvärinen A., Kakkäinen, Vep]alainen A, Hirvonen M-R, Nevalainen A, Clean-Soil, Air, Water, 36(7): 556 (2008).

8. Pasquarella, C., Pitzurra, O., Savino A., J. Hosp Infect, 46: 241(2000).

9. Lacey J., Airborne actinomycete spores as respiratory allergens, In: Schaal K.P. and Pulverer G. (eds), Actinomycetes. Zbl.
Bakteriol. Mikrobiol. Hyg. 1 Abteil. Suppl. Gustav Fischer Verlag, Stuttgart, pp. 243 (1981).

10. Rylander R. and Jacobs R.R., Int J Occup Environ Health 1997; 3: S1-48 (1997).

11. Al-Falih A.M. A., Pakistan J. Biol. Sciences, 4(6): 736 (2001).

12. Al-Sheikh H., Saudi J. Biol. Sci., 15: 237 (2008).

13. Al-Falih A. and Qahtani Y., Saudi Biological Society , 19 $9^{\text {th }}$ Annual Meeting, (1998).

14. Abdel Hafez S. I. I., Mycopathologia, 88: 39 (1984).

15. Abed K.F., J of King Saud University, Science Section, 14, 2, (2000).

16. Mashat B.,Study on airborne microbial content indoor and outdoor of Al Haram mosque during Ramadan 1428H, Technical Report, Umm-Al Qura University, Saudi Arabia, (2009),(in Arabic).

17. CDSI, Central Department of Statistics and Information, Saudi Arabia,(2010).

18. Abdel Hameed A.A. and Abdel Mawla H., Polish J of Environ. Studies, 21: 1539 (2012).

19. El-Gendy S., Biological air pollution at different types of waste handling facilities. Ph.D. Thesis, Faculty of Science, Mansoura Univ., Egypt (2012).

20. Ellis M.,Dematiaceous hyphomycetes, The 
Western Press Ltd, London and Reading Commonwealth Mycological Institute Kew, Surrey, UK,p. 608 (1971).

21. Barnett H.L., Illustrated Genera of Imperfect Fungi, Minneapolis, Minnesota: Burgess Publishing Company (1972).

22. Al-Musallam A., Revision of the black aspergillus species. Ph.D. Thesis, Utrechi, Netherlands, University of Utrecht (1980).

23. Barnett $\mathrm{H}$. and Hunter B., Illustrated genera of imperfect fungi. $4^{\text {th }}$ ed. St. Paul, MN: The American Phytopathological Society, APS; p. 218 (1999).

24. Macher J.M.,Data analysis, Chapter 13. In: Bioaerosols: Assessment and Control, ACGIH Kemper Meadow Drive, Cincinnati, Ohio 45240-1634 (1999).

25. Peccia J., Hospodsky D., Bibby K., Atmos. Environ.,45, 1896(2011).

26. ACGIH, American Conference of Governmental Industrial Hygienists, Bioaerosols: Assessment and Control, ACGIH, Cincinnati, Ohio(1999).

27. Griffin D.W.,Clin. Microbiol. Rev., 20: 459 (2007).

28. Pitzurra M., Pasquarella C., Pitzurra O., Savino A., Ann Ig, 8: 349 (1996).

29. Buttner M.P., Willeke K., Grinspun, S.A Buttner M.P., Willeke K., Grinspun, S.A., Sampling and analysis of airborne microorganisms. In: Hurst C.J., Knudsen G.R., McInerney M.J., Stetzenbach L.D., Walter M.V. (Eds.), Manual of Environmental Microbiology, American Society for Microbiology, Washington, 629 (1997).

30. Nevalainen A.K., Willeke F., Lienhaber J., Pastsuszka A., Burge H., Henningston E.,Bioaerosol sampling: Principles, Techniques and Applications. New York: van Nostrand Reinhold, pp. 471(1993).

31. Nevalainen, A., Bacterial aerosols in indoor air. Ph.D. thesis. University of Kuopio, Kuopio, Finland, pp 58, 66, 73 (1989).

32. ACGIH, American Conference of Governmental Industrial Hygienists. Guidelines for the assessment about aerosols in the indoor environment, Cincinnati, Ohio (1989).

33. WHO, Indoor air quality: biological contaminants: Copenhagen: WHO, Regional
Office for Europe (1990).

34. Polish Standards, PN-89/Z-04111/03 [Polska Norma PN-89/Z- 04111/03]. Protection of air cleanness. Microbiological study. Enumeration of microscopic fungi in atmospheric air (emission) during samples collection by impact and sedimentation methods (1989), (in Polish).

35. Bauer H.; Kasper-Giebl A.; Löflund M.; Giebl H.; Hitzenberger R.; Zibuschka F.; Puxbaum H., Atmos. Res, 64: 109 (2002).

36. Lighthart B., FEMSW Microbiol. Ecol., 23: 263 (1997).

37. Pady S.M., Gregory P.H., Transact. Brit.. Mycol. Soc., 46: 609 (1963).

38. Abdel Hameed A.A., Studies on microbial indicators in ambient air in greater Cairo, Ph.D. thesis Faculty of Science, Mansoura University, Egypt(1996).

39. Lloyd A.B., J. Gen. Microbiol., 57: 35 (1969).

40. Fang Z., Ouyang Z., Zheng H., Wang X., Hu L., Microbial Ecol., 54: 487 (2007).

41. Karra S. and Katsivela E., Water Research, 41: 1355 (2007).

42. Cox C. and Wathes C.,Bioaerosols Handbook, CRC Press LLC, Lewis Publishers(1995).

43. Mouli P.C., Mohan S.V., Reddy S.J.Mouli P.C., Mohan S.V., Reddy S.J., Appl. Ecol. Environ. Research, 3: 139 (2005).

44. Mahdy H.M., El-Sehrawi M.,Water, Air and Soil Pollution, 98: 317 (1996).

45. Burkowska A., KalwasiDska A., Walczak M., Pol. J. Environ. Stud, 21: 307 (2012).

46. Abdul Wahid A., Moustafa A., Moustafa A., Aerobiologia, 12: 249 (1996).

47. Topbas M., Tosun L., Cangamze Kaklikkaya N., Aydin F., Town Turk J. Med. Sci., 36: 31 (2006).

48. Sen B. and Asan A., Environ. Monit. Assess, 15: 209 (2009).

49. Morey P.R., Microbiological investigations of indoor environments: interpreting sampling data-selected case studies, In: Flannigan B, Samson R.A., Miller J.D.: Microorganisms in home and indoor work environments (diversity, health impacts, investigation and control, $2^{\text {nd }} \mathrm{Ed}, \mathrm{CRC}$ press, Taylor and Francis Group (2011).

50. Horner W., Worthan A., Morey P., Appl. 
Environ. Microbiol., 70: 6394 (2004).

51. Lacey J. and Dutkiewicz J., J.Aerosol Sci., 25, 1371 (1994).

52. Campbell C.K., Forms of aspergillosis. In the genus Aspergillus, Edited by KA Powell, A Renwick and JF Poberdy, New York: Plenum, pp 313, (1994).
53. Dutkiewicz, J., Pneumonologia i Alergologia Polska, 60(Suppl 2): 14 (1992).

54. Burrell, R.,Annals of Agr and Environ.Med., 2(1): 11 (1995).

55. Johnson C. L,. Bernstein I. L,. Gallagher J. S., Bonventre P. F., Brooks S. M., Am. Rev. Resp. Dis., 122: 339 (1980). 